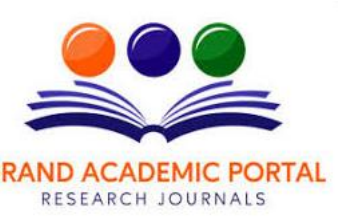

\title{
A STUDY ON PERFORMANCE EVALUATION OF SELECTED MUTUAL FUNDS IN INDIA
}

\author{
CA Jyoti J Patel
}

Chartered Accountant, ICAI, India.

\begin{abstract}
In the Indian Capital market various platforms for the investor to take a position their money for getting more return. Among equity share, bond, Treasury bill, bond, open-end fund then many, but within the Indian capital market, an open-end fund is one among the foremost favorable platforms for an investor to increase their wealth. That is why here we are conducting a study on selected mutual funds in India, the sample of the study is 7 mutual funds The Financial ratio analysis is employed for performance evaluation of fund, therein taking NAV (Net assets value) and return of the three years from 17th July 2017 to 2019. Finding Sharpe ratio, Variance, BETA, and Jenson's alpha on the bases of three-year data. In this study found market sentiment affect more in aggressive hybrid open-end fund compare to conservative.
\end{abstract}

Keyword: Standard deviation, Indian Capital Market, Sharpe ratio, Jenson's Alpha, BETA, Mutual Fund

\section{INTRODUCTION}

Mutual funds are one of the most popular investment options these days. A mutual fund is an investment vehicle formed when an asset management company (AMC) or fund house pools investments from several individuals and institutional investors with common investment objectives. A fund manager, who is a finance professional, manages the pooled investment. The fund manager purchases securities such as stocks and bonds that are in line with the investment mandate.

Mutual funds are an excellent investment option for individual investors to get exposure to an expert managed portfolio. Also, you can diversify your portfolio by investing in mutual funds as the asset allocation would cover several instruments. Investors would be allocated with fund units based on the amount they invest. Each investor would hence experience profits or losses that are directly proportional to the amount they invest. The main intention of the fund manager is to provide optimum returns to investors by investing in securities that are in sync with the fund's objectives. The performance of mutual funds is dependent on the underlying assets.

\section{Types of Mutual Funds}

Mutual funds in India are broadly classified into equity funds, debt funds, and balanced mutual funds, depending on their asset allocation and equity exposure. Therefore, the risk assumed and returns provided by a mutual fund plan would depend on its type. We have broken down the types of mutual funds in detail below:

\section{Equity Funds}

Equity funds, as the name suggests, invest mostly in equity shares of companies across all market capitalizations. A mutual fund is categorized under equity fund if it invests at least $65 \%$ of its portfolio in equity instruments. Equity funds have the potential to offer the highest returns among all classes of mutual funds. The returns provided by equity funds depend on the market movements, which are influenced by several geopolitical and economic factors. The equity funds are further classified as below:

\section{Small-Cap Funds}

Small-cap funds are those equity funds that predominantly invest in equity and equity-linked instruments of companies with small market capitalization. SEBI defines small-cap companies as those that are ranked after 251 in market capitalization.

\section{Mid-Cap Funds}

Mid-cap funds are those equity funds that invest primarily in equity and equity-linked instruments of companies with medium market capitalization. SEBI defines mid-cap companies as those that are ranked between 101 and 250 in market capitalization. 


\section{$\stackrel{0}{=}$ \\ GRAND ACADEMIC PORTAL RESEARCH JOURNALS \\ A GLOBAL JOURNAL OF SOCIAL SCIENCES \\ ( ISSN - 2581-5830 ) \\ Impact Factor: SJIF - 4.998, IIFS - 4.375}

\section{Balanced or Hybrid Mutual Funds}

Balanced or hybrid mutual funds invest across both equity and debt instruments. The main objective of hybrid funds is to balance the risk-reward ratio by diversifying the portfolio. The fund manager would modify the asset allocation of the fund depending on the market condition, to benefit the investors and reduce the risk levels. Investing in hybrid funds is an excellent way of diversifying your portfolio as you would gain exposure to both equity and debt instruments. The debt funds are further classified as below:

\section{Equity-Oriented Hybrid Funds}

Equity-oriented hybrid funds are those that invest at least $65 \%$ of its portfolio in equities while the rest is invested in fixed-income instruments.

\section{Debt-Oriented Hybrid Funds}

Debt-oriented hybrid funds allocate at least $65 \%$ of its portfolio in fixed-income instruments such as treasury bills and government securities, and the rest is invested in equities.

\section{Monthly Income Plans}

Monthly income plans (MIPs) majorly invest in debt instruments and aim at providing a steady return over time. The equity exposure is usually limited to under $20 \%$. You can decide if you would receive dividends on a monthly, quarterly, or annual basis.

\section{Arbitrage Funds}

Arbitrage funds aim at maximizing the returns by purchasing securities in one market at lower prices and selling them in another market at a premium. However, if the arbitrage opportunities are not available, then the fund manager may choose to invest in debt securities or cash equivalents.

\section{LITERATURE REVIEWS}

S TRIPATHI, DRGP JAPEE (2020) researched fifteen equity mutual funds of different categories based on the market capitalization of companies. Used different financial ratios for the evaluation of funds. They found most equity mutual funds are performing well, but when a sharp fall in NIFTY 50 in 2019 is affecting the return of the mutual fund.

KB Sharma (2020) found that three funds have performed well, and two funds had not performed well during the study period from the selected five Debt funds. The sharp fall in the NIFTY during the year 2019 has impacted the performance of all the selected funds. statistical parameters used for performance evaluation were alpha, beta, standard deviation.

S Tripathi (2020) concluded that people are aware of a mutual fund but still, very few peoples are investing in mutual funds. Respondents are preferring equity, hybrid \& debt, respectively. $75 \%$ of respondents are preferring a Systematic Investment Plan (SIP). Respondents are also aware of share market functioning. Respondents know that the Asset Management Company (AMC) invest their money in Share Market. Primary data was used for research.

CMA Panigrahi et. al (2020) studied an analysis of ten equities linked saving scheme mutual funds. Using financial ratios and tools for analysis including the average return, coefficient of determination (R2), S.D, Beta, Sharpe ratio, Jensen alpha. They found a more attractive return in ELSS mutual funds and takes a tax benefit of 1.5 lakh.

\section{OBJECTIVE OF STUDY}

- The main purpose of the study is to get information about the performance of mutual funds in India.

- To look at the arrival from the selected equity mutual funds

- To look at the arrival from the selected mutual funds in India.

- To identified security market return with fund return.

- Finding out that Mutual fund is good investment instrument for investors.

\section{RESEARCH METHODOLOGY}

\section{Sources of Data}

These data examination depends on secondary data collected from various Asset Management Companies (AMCs). 


\section{$\stackrel{00}{=}$}

GRAND ACADEMIC PORTAL RESEARCH JOURNALS

\section{A GLOBAL JOURNAL OF SOCIAL SCIENCES}

( ISSN - 2581-5830 )

Impact Factor: SJIF - 4.998, IIFS - 4.375

\section{Duration of study}

Three years from 17th July 2017 to 2019

\section{Parameters for analysis}
1) Returns
2) Standard Deviation
3) Beta
4) Sharpe ratio
5) Jensen's ratio

\section{DATA ANALYSIS}

Table 1 Conservative funds

\begin{tabular}{|c|c|c|c|c|c|c|c|}
\hline No. & Fund name & $\begin{array}{l}\text { NAV for } \\
2017\end{array}$ & $\begin{array}{l}\text { Return for } \\
2017\end{array}$ & $\begin{array}{ll}\text { NAV } & \text { for } \\
2018 & \end{array}$ & $\begin{array}{l}\text { Return for } \\
2018\end{array}$ & $\begin{array}{ll}\text { NAV } & \text { for } \\
2019 & \end{array}$ & $\begin{array}{l}\text { Return for } \\
2019\end{array}$ \\
\hline 1 & IDBI Hybrid & 11.59 & $1.02 \%$ & 12.46 & $-2.00 \%$ & 11.69 & $1.80 \%$ \\
\hline 2 & $\begin{array}{l}\text { ICICI } \\
\text { Prudential } \\
\end{array}$ & 38.33 & $6.61 \%$ & 40.22 & $7.45 \%$ & 43.53 & $6.68 \%$ \\
\hline 3 & $\begin{array}{ll}\text { Kotak } & \text { Debt } \\
\text { hybrid } & \\
\end{array}$ & 29.21 & $5.34 \%$ & 29.46 & $7.64 \%$ & 31.83 & $7.28 \%$ \\
\hline 4 & $\begin{array}{l}\text { DSP eq.\& bond } \\
\text { fund }\end{array}$ & 138 & $3.46 \%$ & 145.28 & $3.59 \%$ & 156.54 & $1.79 \%$ \\
\hline 5 & JM Eq. hybrid & 43.64 & $0.86 \%$ & 45.48 & $-0.77 \%$ & 41.18 & $-8.72 \%$ \\
\hline 6 & LIC MF Hybrid & 50.61 & $6.01 \%$ & 51.77 & $7.93 \%$ & 55.89 & $7.88 \%$ \\
\hline 7 & SBI Debt & 37.80 & $3.69 \%$ & 37.89 & $5.45 \%$ & 39.90 & $5.60 \%$ \\
\hline
\end{tabular}

Chart 1

\section{Net Asset Value(NAV)}

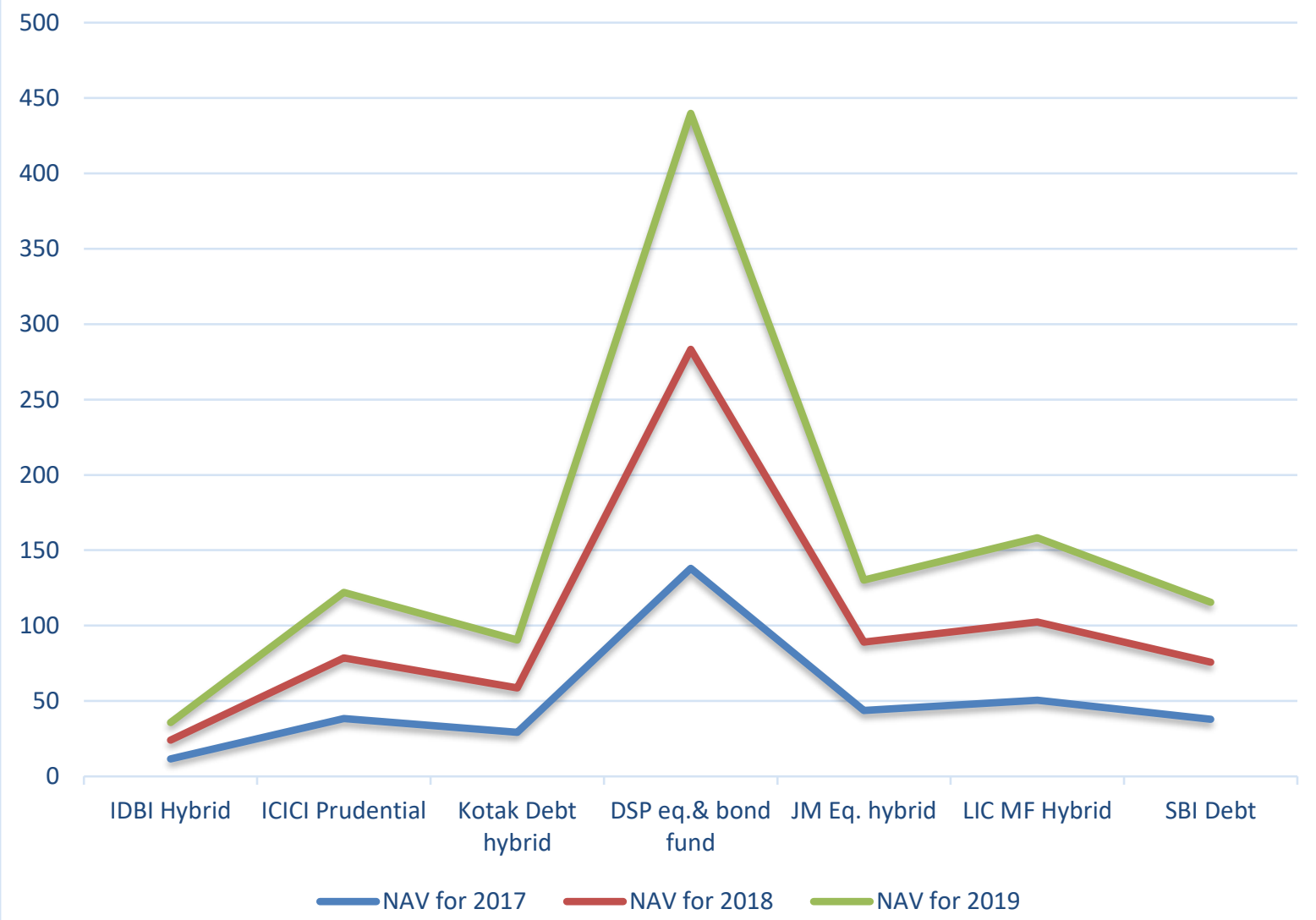




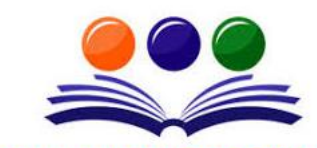

GRAND ACADEMIC PORTAL RESEARCH JOURNALS
A GLOBAL JOURNAL OF SOCIAL SCIENCES

( ISSN - 2581-5830 )

Impact Factor: SJIF - 4.998, IIFS - 4.375

\section{Chart 2}

\section{Returns}

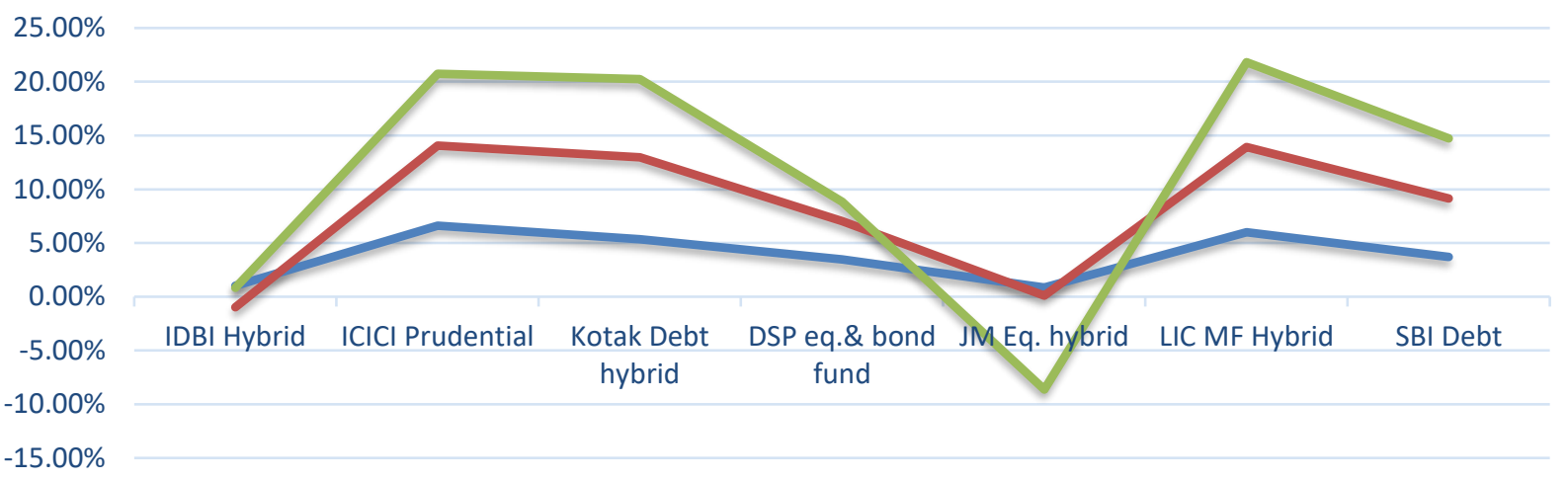

Return for 2017 Return for $2018 \quad$ Return for 2019

\begin{tabular}{|l|l|c|c|c|c|}
\hline \multirow{2}{*}{ No. Fund name } & \multicolumn{1}{c}{$\begin{array}{c}\text { Table 2 Aggressive fund } \\
\text { STANDARD DEVIATION }\end{array}$} & BETA & $\begin{array}{c}\text { SHARPE } \\
\text { RATIO }\end{array}$ & $\begin{array}{c}\text { JENSON'S } \\
\text { ALPHA }\end{array}$ \\
\hline $\mathbf{1}$ & IDBI Hybrid & 12.69 & 0.94 & -0.27 & -5.67 \\
\hline $\mathbf{2}$ & ICICI Prudential & 4.45 & 0.88 & 0.52 & -1.25 \\
\hline $\mathbf{3}$ & Kotak Debt Hybrid & 5.71 & 1.2 & 0.21 & -3.59 \\
\hline $\mathbf{4}$ & DSP Eq.\& Bond & 14.9 & 8.47 & 0.08 & -22.02 \\
\hline $\mathbf{5}$ & JM Eq. funds & 15.66 & 1.02 & -0.46 & -9.61 \\
\hline $\mathbf{6}$ & LIC MF hybrid & 4.21 & 0.85 & 0.38 & -1.76 \\
\hline $\mathbf{7}$ & SBI Debt & 5.29 & 1.08 & -0.07 & -4.69 \\
\hline
\end{tabular}

\section{Financial Ratios}

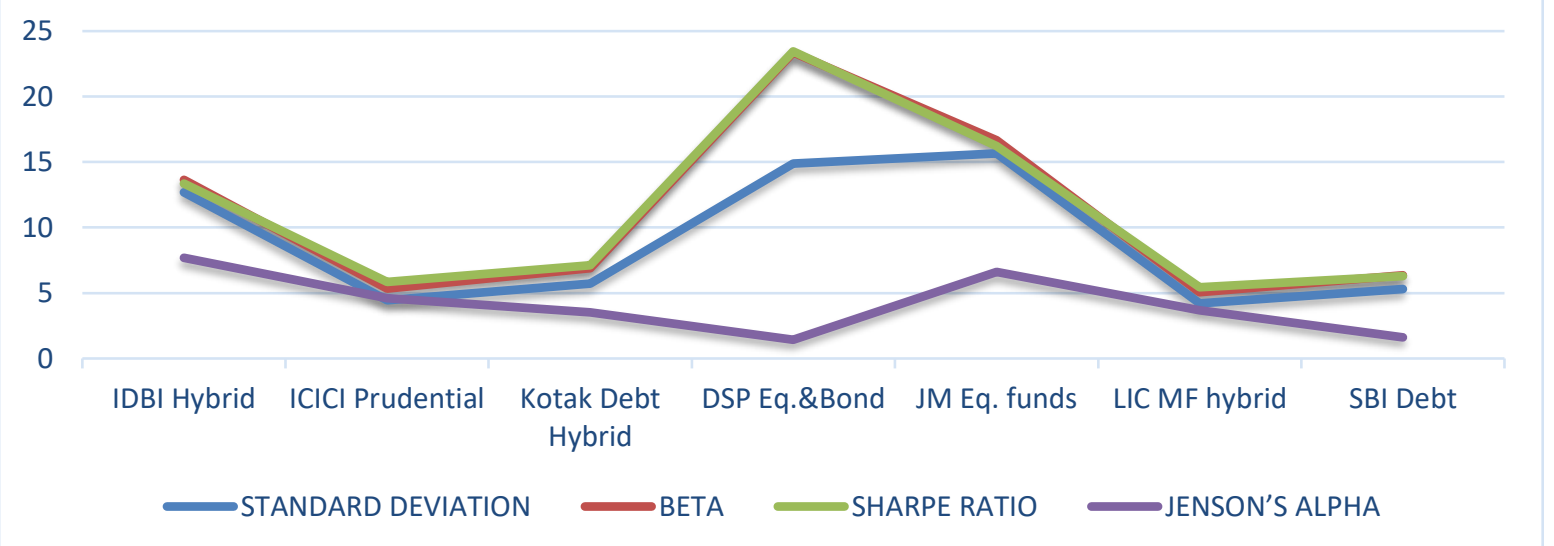

\section{FINDINGS}

At the end of the year 2017 NAV \& TOTAL RETURN for selected schemes (IDBI Hybrid $11.59 \& 1.02 \%$, ICICI Prudential 38.33 \& 6.61\%, Kotak Debt Hybrid 29.21 \& 5.34\%, DSP Eq.\&Bond 138 \& 3.46\%, JM Eq. funds 43.64 \& $0.86 \%$, LIC MF hybrid50.61 \& 6.01\%, SBI Debt 37.80 \& 3.69\%)

At the end of the year 2017 NAV \& TOTAL RETURN for selected schemes (IDBI Hybrid $12.46 \&-2.00 \%$, ICICI Prudential 40.22 \& 7.45\%, Kotak Debt Hybrid 29.46 \& 7.64\%, DSP Eq.\&Bond 145.28 \& 3.59\%, JM Eq. funds 45.48 \& $-0.77 \%$, LIC MF hybrid 51.77 \& 7.93\%, SBI Debt 39.90 \& 5.60\%) 


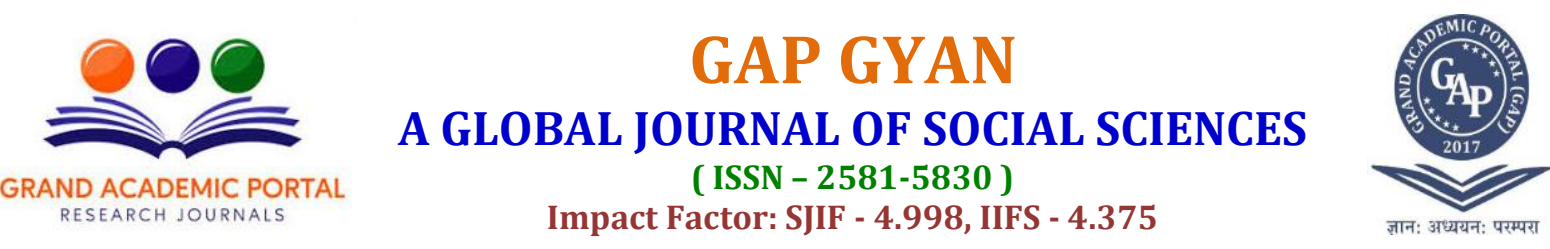

At the end of the year 2017 NAV \& TOTAL RETURN for selected schemes (IDBI Hybrid $11.69 \& 1.02 \%$, ICICI Prudential 38.33 \& 6.61\%, Kotak Debt Hybrid 29.21 5.34\%, DSP Eq.\&Bond 138 \& 3.46\%, JM Eq. funds 43.64 \& 0.86\%, LIC MF hybrid50.61 \& 6.01\%, SBI Debt 37.80 \& 3.69\%)

In IDBI Hybrid Fund it has a standard deviation of fund is 12.69 and beta value of the fund is 0.94 which means the fund is low volatile and where it has Sharpe's Ratio of the fund is -0.27 and Jenson's Alpha of fund is -5.67 which says that the fund is a better risk-adjusted return to benchmark indices, and it has performed well by providing a better return to the investors.

In ICICI Prudential Fund it has a standard deviation of fund is 4.45 and beta value of the fund is 0.88 which means the fund is very low volatile and where it has Sharpe's Ratio of the fund is 0.52 and Jenson's Alpha of fund is $(-1.25)$ which says that the fund is a better risk-adjusted return to benchmark indices, and it has performed well by providing a better return to the investors.

In KOTAK Debt Hybrid Fund, it has a standard deviation of fund is 5.71 and beta value of the fund is 1.2 which means the fund is very low volatile and where it has Sharpe's Ratio of the fund is 0.21 and Jenson's Alpha of fund is (-3.59) which says that the fund is a better risk-adjusted return to benchmark indices, and it has performed well by providing a better return to the investors.

In DSP Equity \& Bond Fund it has a standard deviation of fund is 14.9 and beta value of the fund is 8.47 which means the fund is very high volatile and where it has Sharpe's Ratio of the fund is 0.08 and Jenson's Alpha of fund is (-22.02) which says that the fund is a very poor risk-adjusted return to benchmark indices, and it has not performed well by providing a poor return to the investors.

In JM Equity Fund it has a standard deviation of fund is 15.66 and beta value of the fund is 1.02 which means the fund is very high volatile and where it has Sharpe's Ratio of the fund is - 0.46 and Jenson's Alpha of fund is (9.61) which says that the fund is a very poor risk-adjusted return to benchmark indices, and it has not performed well by providing a poor return to the investors.

In LIC Hybrid Mutual Fund it has a standard deviation of fund is 4.21 and beta value of the fund is 0.85 which means the fund is very high volatile and where it has Sharpe's Ratio of the fund is 0.38 and Jenson's Alpha of fund is $(-1.76)$ which says that the fund is a very poor risk-adjusted return to benchmark indices, and it has not performed well by providing a poor return to the investors.

In SBI Debt Fund it has a standard deviation of fund is 5.29 and beta value of the fund is 1.08 which means the fund is very high volatile and where it has Sharpe's Ratio of the fund is -0.07 and Jenson's Alpha of fund is (4.69) which says that the fund is a very poor risk-adjusted return to benchmark indices, and it has not performed well by providing a poor return to the investors.

\section{CONCLUSION}

The study is conducted based on seven selected mutual funds. From the foregoing performance analysis of the selected seven funds, 3 funds have performed well, and 4 funds had not performed well during the study period. In the ultimate analysis, it may be concluded that all the funds have performed well in the high volatile market movement expect DSP equity \& bond fund, JM Equity fund, LIC Hybrid Mutual Fund, SBI Debt Fund. Therefore, investors need to consider statistical parameters like Jenson's alpha, beta, standard deviation, Sharpe Ratios while investing in mutual funds apart from considering NAV and Total Return to ensure consistent performance of mutual funds.

\section{REFERENCES}

[1] TRIPATHI, S., \& JAPEE, D. G. P. (2020). PERFORMANCE EVALUATION OF SELECTED EQUITY MUTUAL FUNDS IN INDIA.

[2] Sharma, K. B. (2020). PERFORMANCE ANALYSIS OF MUTUAL FUND: A COMPARATIVE STUDY OF THE SELECTED DEBT MUTUAL FUND SCHEME IN INDIA.

[3] Tripathi, S. (2020). AN EMPIRICAL STUDY OF MUTUAL FUND AWARENESS AMONG THE PEOPLE OF AHMEDABAD.

[4] Panigrahi, C. M. A., Mistry, M., Shukla, R., \& Gupta, A. (2020). A Study on Performance Evaluation of Equity Linked Saving Schemes (ELSS) of Mutual Funds. NMIMS JOURNAL OF ECONOMICS AND PUBLIC POLICY, 5(1).

[5] www.cleartax.com

[6] www.amfi.com 